\title{
The Impact of Farmer Field Schools (SLK) Program Implementation on the Cocoa Farm Business in Lima Puluh Kota Regency
}

\author{
Walmadri ${ }^{1}$, Hasnah ${ }^{2}$, Faidil Tanjung ${ }^{3}$ \\ Magister Program in Agricultural Economics Faculty of Agriculture, \\ Andalas University, Padang 25163 \\ Email :1' walmadriselah@gmail.com ${ }^{2}$ annase69@g mail.com, ${ }^{3}$ faidilt@yahoo.com.
}

\begin{abstract}
Cocoa industry in West Sumatra has high potential to increase the income of small farmers. However, cocoa production is still below production potential. The implementation of the cocoa field school program (SLK) is one of approaches to develop cocoa farm business. This field school is expected to improve the performance of smallholders' cocoa farming, both in terms of production and quality. To assess the extent to which this field school has helped farmers to increase their capacity to manage cocoa farming, research is needed to analyze the impact of the implementation of the farmer field school program on cocoa farming as measured by level of technology adoption and economic impact by comparing cocoa income between participant and non-participant farmers in farmer field school program. The study was conducted in Lima Puluh Kota Regency which involved a sample of 80 people, consisting of 40 SLK farmers and 40 non-SLK participants. The results showed that forthe impact of the SLK on cocoa farming, it was found thatfor the price variable there was a significant difference but for the variable production, farming costs and income between farmers and non-SLK participants there were no significant differences. In conclusion that the cocoa field school program has not significantly affected cocoa farming practices in Lima Puluh Kota. As a result, the expected increase in production and quality of cocoa has not been achieved. Keywords- production and quality, farmers field school, cocoa.
\end{abstract}

\section{INTRODUCTION}

Field School concept is not new in the field of agriculture Indonesia. Introduced in 1989 by the Food and Agriculture Organization (FAO) as an effort integrated pest management, farmer field schools invited to learn directly in the field, observed the problem and its causes, as well as to analyze the development of their crops. Implementation of a field school for many years in various regions in Indonesia is considered a major role in helping farmers reduce the use of pesticides and increase yields (worldagroforestry, 2013). The Field School is seen as one of the methods in the learning process is quite effective, because it is very suitable as a learning method for adults (andragogy) because it is not formal.

Schools field is already widely practiced in the agricultural sector in Indonesia. Implementation of a field school for many years in various regions in Indonesia is considered a major role in helping farmers reduce the use of pesticides and increase yields. Various agencies in Indonesia either government or private institution has conducted a field school in various agricultural sub-sector either sub-sectors of food, horticulture and plantation subsector.

Field school activities undertaken in the plantation sector sub one on the plantation of cocoa by name by Cocoa Field School Program (SLK). The importance of the cocoa field school activities is to increase the production and quality of the cocoa bean itself. Currently Indonesia is the world's third largest producer of cocoa after Evory Coast (Cote d'Ivoire) and Ghana. Indonesian cocoa plantation area was recorded of 1.4 million hectares with a production of approximately 500 thousand tons per year. Ivory Coast ranks first largest cocoa-producing country has a total area of 1.6 million hectares with a production of 1.3 million tons per year and Ghana amounted to 900 thousand tons per year (Ardhiyan, 2015).

Terms of the exploitation of the cocoa able to absorb the labor force large enough, since nationally nearly 87 percent of the development of cocoa grown by smallholder, while the remainder raised by the State Great Estates and Private Big Plantation. And the contribution of energy absorption kerjA for the overall cocoa around 7.8 percent. (Dirjenbun, 2016).

Nationally although cocoa plantation area tends to increase, but not accompanied by peningatan contrary cocoa production cocoa production has decreased. At the beginning of 2010, the production of cocoa plantations of people initially fell to 701229 tonnes 837918 tonnes in 2015 (Dirjenbun, 2016). 
Increased cocoa plantation area that is not accompanied by an increase in cocoa production is caused by many factors, one of which is for tarjadinya La Nina, rainfall hujan high so as to make the cocoa plant experienced a compounded interest kerontokoan cocoa plant shortlyjadi highly vulnerable to pests and diseases such as pest PBK (Cocoa Fruit Borer) and disease dieback /VSD (Vascular Streak Dieback) which eventually led to the production of cocoa shortlyjadi disturbed (Zulhefi, 2015).

Therefore, efforts need to be done in order to repair the national cocoa production can be maintained and even improved. Repair cocoa plantations can be done through the rehabilitation, rejuvenation and expansion with superior plant material and application of advanced technologies. In addition, efforts to control pests and diseases PBK VSD must be intensified (Pulsitbangbun, 2017).

All this has made various efforts to improve conditions such as the empowerment of farmers through the Field School of the cocoa (SLK) or Field School Integrated Pest Management (IPM FFS) and System Togetherness Economics (SKE), as well as the application of control technology by methods PsPSP (pruning, sanitation, harvest often andfertilization) for CPB and VSD control and the provision of seedssuperior. Given the partial implementation is still small in scale, the results are not optimal. Therefore, these activities need to be carried out simultaneously, comprehensive and integrated through a movement that involves all stakeholders and resources (Directorate General of Plantation of the Ministry of Agriculture, 2012).

In addition to government agencies, private organizations also intervened in the repair of cocoa in Indonesia such Governmental Organization Save The childern funded by Mondelez and NGO Swisscontact sustainable cocoa production program or The Sustainable Cocoa Production Program(SCPP).

Swisscontact is a Non Governmental Organization (NGO) International founded by private and educational institutions in Switzerland in 1959.The Sustainable Cocoa Production Program (SCPP) is the program of Swisscontact is a partnership Public-Private large that began in 2012 with the main focus on building a better capacity between the cocoa farmers to improve the quantity and quality of cocoa production (Swisscontact, 2014).

District Fifty town is located in the province of West Sumatra is one area that is a center of folk and cocoa plantation development has been fostered by Swisscontact in economic capacity building, gardens and surroundings cocoa farmers. This is supported by state of the climate and soil in accordance with the terms of plantation crops specifically grown for cocoa plantations.
Swisscontact main objective is to help the Indonesian cocoa farmers create sustainable cocoa products. With a program calledThe Sustainable Cocoa Production Program (SCPP), which is a program to create a cocoa plantation promising and sustainable both for the farmers, the environment and the market. The main focus of the program is to build capacity SCPP is better between the cocoa farmers in order to increase the quantity and quality of cocoa production.

SCPP program is run in the form of cocoa field school for cocoa farmers who joined as a participant. Various training in cocoa field school has been given by the NGO Swisscontact some of which are field schools on cocoa farming practices are good and true as materials about pruning, fertilizing, field sanitation, frequent harvesting, pest and disease control and post-harvest.

In the year of 2017 activities and assistance with cocoa field school program of non-governmental organizations Swisscontact has been done in District Fifty Cities and has trained farmer groups with a total of 16 groups of farmers 400 people with these types of programs are the activities carried out; (1) good agricultural practices and technology transfer system; (2) Integration of Nutrition and gender sensitivity; (3) The organization of farmers, access to market and certification; (4) an integrated financing facility; (5) Management of stakeholders and networking platform.

\section{Identification of problems}

Of the five programs over the study will focus on discussing the impact of the implementation of good agricultural practices and the transfer system electronic technology, so it appears some of the questions the research is "Is the Field School of Cocoa (SLK) are undertaken by NGOs Swisscontact able to increase the ability of farmers in cocoa farming?"

\section{Research purposes}

Based on the background and the problems above, this research aims to "analyze the impact of cocoa field school program provided by Swisscontact to as sisted farmers in the District Fifty Cities in terms of production, sales price, the cost of farming and income?"

\section{hypothesis}

"Cocoa Field School Has Real Impact Of Cocoa Farming in the District Fifty Cities".

\section{RESEARCH METHODS}

\section{Types of research}

The method used in this research is descriptive method with case study. Descriptive method is a method in researching a group of people, an object is a system of thought or a class of events in the present. The purpose of 
this descriptive study is to create a description, picture of systematic, factual and accurate information on the facts as well as the relationship between the phenomenon investigated. The case study research on the status of research subjects that relate to a specific phase or typical of the whole personality. The research subject can be individuals, groups, institutions and communities (Nazir 2005: 54-55).

\section{Research variable}

Based on the research objectives of variables variables were observed in this study are:

1. Total production is the result obtained by farmers in the cocoa farming obtain cocoa field school program or not.

2. Cocoa bean prices received by farmers, is a monetary compensation received by farmers every cocoa bean sales in a matter of kilograms.

3. Cocoa farming costs, is the value of being sacrificed to obtain the factors of production used in farming.

4. Cocoa farm income, the difference between the total revenue with costs incurred tottal.

\section{Sampling method}

The sampling technique in this research using the technique of simple random sampling (simple random sampling techniques). Kasmadi and Sunariah (2013: 66) argues that "the simple random sampling technique is simple sampling technique is done randomly without regard to strata that exist in the population" as the basic principle of making members of the sample who expressed W.Gulo (2002: 84) that "that each member of the population has an equal chance to be drawn as members of the sample".

According Sugiyono (2008: 116) "sample is part of the number and characteristics possessed by this population." Meanwhile, according Arikunto (2008: 116) "Determination of sample taking is when a population of less than 100 better taken all until the research is the study population. If a large number of subjects can be taken between $10-15 \%$ or $20-55 \%$ or more depending somewhat on:

1. The ability of researchers seen from the time, effort and funds

2. Narrow the breadth of observations from each subject area, because it involves a lot of lack of funds.

3. The size of the risk borne by researchers for researchers, the risk is great, of course if large samplenya result will be better

Thus, the researchers took a number of samples required as a source of data in this study is $10 \%$ of the total population or $10 \% \times 400=40$, so that the sample in this study amounted to 40 cocoa farmers get a field school program cocoa and 40 farmers do not get the cocoa field school program, so the total sample is keseluruahan numbered 80 people spread over three districts namely Payakumbuh District, District Guguak, District Mungka.

Method of collecting data

1. Primary data

Data is taken directly from the interviews with key informants namely Field Staff Coordinator along Swiscontact NGOs in the district Fifty Cities, and some people from Swiscontact assisted farmers and growers from outside the assisted farmers to be used as a control or comparison.

2. Secondary Data

Data is a form of writing or document relating to the problems of research, obtained from literature study, document organization, as well as the relevant literature such as books, journals and research reports related to the research. In this study, secondary data collected comes from Lemabaga Governmental Swisscontact and related agencies such as the Department of Plantations Kabupatrn 50 State, Department of Trade and Industry, literature and other written sources related to this research.

\section{Data analysis method}

For analyzing the impact of field school program cacao given by Swisscontact to assisted farmers in the District Fifty Cities in terms of production, prices and costs of farming using quantitative descriptive method by using analytical tools questionnaires and interviews, see the benefits received by the assisted farmers in terms of production and a reduction in farming costs. To test the hypothesis proposed in this study conducted a comparative analysis (t-test), comparing the condition of farmers get with the program that did not get the SLK SLK program.

According Sugiyono (2009: 264) to test samples correlated / paired t-test then used the samples related to the formulation as follows:

$$
t=\frac{-\overline{\mathrm{x}_{1}}-\overline{\mathrm{x}_{2}}}{\sqrt{\frac{\mathrm{S}_{1}^{2}}{\mathrm{n}_{1}}+\frac{\mathrm{S}_{2}^{2}}{\mathrm{n}_{2}}-2 \cdot \mathrm{r}\left(\frac{\mathrm{s}_{1}}{\sqrt{\mathrm{n}_{1}}}\right)\left(\frac{\mathrm{s}_{2}}{\sqrt{\mathrm{n}_{2}}}\right)}}
$$

Where :

$$
\begin{gathered}
-\mathrm{t}=\text { The value of the region } \\
\text { criticism }\left(\mathrm{t}_{\text {count })}\right. \\
\overline{\mathrm{X}_{1}}= \\
\text { The average value of } \\
\text { production, prices, costs and } \\
\text { incomes of cocoa farmers } \\
\text { who do not get the program } \\
\text { SLK }
\end{gathered}
$$


- $\overline{\mathrm{X}_{2}}=$ The average value of production, price, cost and income of cocoa farmers get SLK program

- $\mathrm{s} 1=$ standard deviation value of production, prices, costs and incomes of cocoa farmers who do not get the program SLK

- s2 = Standard deviation value of production, price, cost and income of cocoa farmers get SLK program

- $\mathrm{S} 21=$ Variance of production, prices and the cost of cocoa farmers who do not get the program SLK

- $\mathrm{S} 22=$ Variance of production, prices and the cost of cocoa farmers get SLK program

- $\mathrm{r}=$ Correlation between production, prices, costs and incomes of cocoa farmers are not getting to the get the program SLK

- $\mathrm{n} 1=$ Number of samples that did not get the program SLK

- $\mathrm{n} 2=$ Number of samples mendapatakan SLK program

Forms of statistical hypothesis is:

- $\mathrm{H} 0: \mu 1=\mu 2$ (there are no significant differences between production, prices, costs and incomes of cocoa farmers are not getting to the get the program SLK)

- H1: $\mu 1>\mu 2$ (there are significant differences between production, prices, costs and incomes of cocoa farmers are not getting to the get the program SLK)

The data were processed using SPSS with hypothesis testing criteria as follows: 1) If the probability (p) $<0.01$ or 0.05 or by other means $t>t$ table then $\mathrm{H} 0$ rejected 2) If the probability $(p) \geq 0.01$ or 0.05 or otherwise $\mathrm{t} \leq \mathrm{t}$ table then $\mathrm{H} 0$ is accepted.

\section{RESULTS AND DISCUSSION \\ Regional Overview Research \\ Geography and Regional Administration}

District Fifty Town area of $3354.30 \mathrm{~km} 2$, located in the eastern part of West Sumatera, namely $0022 \mathrm{~N}$ and 00 23'LS and between $110016^{\prime}-1000$ 51'BT and the adjacent province of Riau. Government administrative region comprising 13 districts with 76384 Jorong Nagari and has a population of 327652 inhabitants in the area and boundaries as follows:

$\begin{array}{lll}\text { The North } & : \text { Riau Province } \\ \text { Eastern section } & : \text { Riau Province } \\ \text { South side } & : \text { Tanah Datar and Sijunjung } \\ \text { West Region } & : \text { Agam and Pasaman }\end{array}$

\section{Total population}

District residents Fifty Cities in 2016 amounted to 372568 people, with details of 184995 inhabitants male and 187573 female inhabitants. Judging by the number of villages in the district Fifty Cities as many as 79 villages, then with a population of 372568 inhabitants, the average number of residents per village amounted to 4,716 people. District of highest average is the District Guguak by the number of 7,260 people per village.

Population by age group in the District Fifty Cities still dominated by young people aged. The age group is the most numerous group of $0 \mathrm{~s} / \mathrm{d} 4$ years with a total of 38285 inhabitants, while the smallest number is a group of $60 \mathrm{~s} \mathrm{/} \mathrm{d} 64$ years in the amount of 16112 inhabitants.

Profile Cocoa Farming between Farmers Field School Getting the cocoa With Non Getting Farmers Field School in the District Cocoa Fifty Cities

Here is a table showing the amount of Production, Productivity, Price, Cost Farm and Farmers Income Respondents in the Dis trict Fifty Cities 2018:

Table.21. Number of Production, Productivity, Price, Cost Farm and Farmers Income Respondents in the District Fifty Cities 2018

\begin{tabular}{lrr}
\hline \multicolumn{1}{c}{ Component } & farmers SLK & \multicolumn{1}{c}{ Farmers Non SLK } \\
\hline $\begin{array}{l}\text { Production } \\
\text { (Kg / year) }\end{array}$ & 21402 & 1937 \\
$\begin{array}{l}\text { Productivity } \\
\text { (Kg / ha / year) } \\
\text { The average price Dried Cocoa Beans (per kg) }\end{array}$ & 535 & 488 \\
\end{tabular}


(Rp.)

Average Cost Farming (per ha / year) (Rp.)

Average - Average income (per ha / year) (Rp.)

$10,757,045$

9.63563 million

Source: Primary Data Processing 2018

\section{Farming costs}

Production Costs According Wasis (1992), production costs are sacrifices that absolutely must be held in order to obtain a result. In this study a year for the maintenance of the average farmer only cost in the form of production, purchase organic fertilizers, chemical fertilizers, pesticides, herbicides and labor.

Most farmers only pay for the purchase of organic fertilizer, and labor for more emphasis on family workers, arguing that they lack of money to buy other needs in the treatment of cocoa. Only a small proportion of farmers who want to spend more money to purchase chemical fertilizers, pesticides and labor.

In table 15 can be seen average farm costs incurred by the farmer respondents averaged annually after the results obtained to farming costs incurred by farmers who get SLK Rp. 2,883,837 / ha / year and for farmers who do not get SLK Rp. 2,579,174, for a more detailed data can be found in appendix $12 \mathrm{~s} / \mathrm{d} 15$.

\section{Production}

Results obtained from the cacao plant is wet cocoa beans and farmers sell in the form of dried cocoa beans at random, where the cocoa beans have been dried 1-2 days ( 1 day $=2-5$ hours drying). After drying, the water content contained in cocoa beans and cocoa beans decreases will experience a depreciation of $25 \%$ (100 kg wet cocoa beans will be $75 \mathrm{~kg}$ of dried cocoa beans at random).

Based on the results of this research is that the amount of the average production of cocoa every farmer in the district of Fifty Cities are getting SLK amounting to $21402 \mathrm{~kg} /$ year with a productivity of $535 \mathrm{~kg} / \mathrm{ha} /$ year, whereas for farmers who do not get SLK production amounted to $19537 \mathrm{~kg}$ / year and a productivity of $488 \mathrm{~kg}$ / ha / year. Total production and productivity of cocoa in one year can be seen in the following table:

From table 15 it can be analyzed that there is little difference between farmers and non SLK SLK in terms of production and productivity but the differences are not too significant. When viewed as a whole both production and non-farmers SLK SLK (annex $12 \mathrm{~s} / \mathrm{d}$ 15) exist that have high production and there is also low. Analysis by researchers in the field main factors that affect farmers' production is in terms of the intensity of the maintenance of the garden each farmer. If farmers diligently perform lawn care such as pruning and fertilizing the resulting production will also be high and vice versa if farmers rarely do care then the resulting production will be low, usually farmers who rarely perform maintenance go kekebun cocoa just to harvest.

\section{Selling Price of Cocoa Beans}

For the price of cocoa beans in the City District Fifty average farmer selling dried cocoa beans to a collector for the village / market. Most of the farmers who have the production of cocoa beans $<50 \mathrm{~kg}$ per week were more likely to sell to a collector for the village and which has production $>50 \mathrm{~kg}$ prefers to sell directly to the market / wholesalers in the county because of the price between traders gatherer village with pedangan large in the county ranges from Rp. 1000, - s / d

Rp 2,000, -.

In this study, researchers will set the price farmers with farmers Non SLK SLK traders village level. The price of cocoa beans in each farmer will be different from one another, depending on the quality of cocoa beans are produced. Based on the research results at the same time each farmer to get a different price ranges between Rp. 24000, - s / d Rp.27.000 and the price evenly between peasant farmers with Non SLK SLK (annex $12 \mathrm{~s}$ / d 15) that sets it apart is if the cocoa produced by farmers good / high quality, the price obtained will be high and vice versa if the quality of cocoa produced by farmers ugly / poor quality, the price obtained is also low. Cocoa quality are generally grouped into three muti / grade (Attachment 5) and measured based on the number of moldy grain moisture content, attached, deflated, and trash (something other than beans).

\section{Farmers' income}

Cocoa farmers' income is the difference between total revenue with total costs incurred in cocoa farming activities. In this study, the majority of farmers only pay the cocoa farm just to purchase organic fertilizer (compost / manure), only a fraction is spend on the purchase of chemical fertilizers, pesticides, herbicides and labor. From the results of primary data processing for the income of farmers in the $\mathrm{Ha} /$ year can be seen in appendix $12 \mathrm{~s} / \mathrm{d} 15$.

Based on the attachment $12 \mathrm{~s} / \mathrm{d} 15$ in one ha / year farmers are able to earn an income between Rp. 4.000.000, - s / d Rp. 26,000,000, - both farmers and non SLK SLK there who have low income and there is also a high everything depends on the production produced and the prices received by each farmer. Farmers will have a high income and high production if otherwise farmers will get a lower price when production is low, while the 
level of production is determined on the level of lawn care, and the price level is determined by the quality of the cocoa beans are produced.

\section{Test T-Test}

Analysis of this data aims to test the hypothesis of the research is to determine the difference production, prices, costs and incomes of farming cocoa farmers get with the program that did not get the SLK SLK program, Forms of statistical hypothesis is:

- H0: $\mu 1=\mu 2$ (there are no significant differences between production, prices, costs and incomes of cocoa farmers are not getting to the get the program SLK)

- $\quad H 1: \mu 1>\mu 2$ (there are significant differences between production, prices, costs and incomes of cocoa farmers are not getting to the get the program SLK)

The hypothesis in this study were tested using the Test-T. The first step taken was to develop formulations. Through the preparation of such formulations formulated the t-test test formula used is bidirectional (two-tailed test) with menggunankan Microsoft Excel. Once it was determined the level of significance that is at the level of $10 \%$. The provision in question is, if the significance value is smaller than the significance level of $10 \%$ and $\mathrm{T}$ count is greater than the T-table at a significance level of
$10 \%$ then $\mathrm{H} 0$ rejected and $\mathrm{H} 1$ accepted. Conversely, if the use values of $\mathrm{T}$-count is smaller than the T-table at a significance level of $10 \%$ then $\mathrm{H} 0$ and $\mathrm{H} 1$ rejected.

2 different test average (Independent Samples TTest) is used to determine whether there are differencesSignificant among production, prices, costs and incomes of cocoa farmers are not getting to the get the program SLK, Tests using a significance level of 0.1 . Before the 2 different test performed on average, $F$ test (Test Homogeneous) need to be done first. If the same variant, the Equal Variance $t$ test using Assumed (assumed to be the same variant) and, if different variants using Unequal Variance Assumed (assumed different variants).

The results of hypothesis testing can be seen in appendix 17 and 18 for the $F$ test each variable. variablesproduction obtained $\mathrm{F}$-count $=1,20<\mathrm{F}$-table $=$ 1.70 thus to homogeneous production variants. Variable Price obtained the F-count $=2.56>$ F-table $=1.70$ thus to the price variance is not homogeneous. Variable Cost Farming obtained F-hiutng $=0,89<$ F-table $=1.70$ thus to variant variables Farming fee is homogeneous. Variable Income earned F-count $=1,41<$ F-table $=1.70$ thus to variant Revenue variable is homogeneous. So to test variable $\mathrm{T}$ production, farming costs and revenues usingEqual Variance Assumed and for variable prices using Unequal Variance Assumed.

Table.22: Results of Testing Test $F$

\begin{tabular}{lccll}
\hline \multicolumn{1}{c}{ Component } & F-count & F-table & \multicolumn{1}{c}{ result } & \multicolumn{1}{c}{ test T } \\
\hline Production & 1.20 & 1.70 & F arithmetic $<$ F table & Equal Variance Assumed \\
Price & 2.56 & 1.99 & F count $>$ F table & Unequal Variance Assumed \\
Farming costs & 0.89 & 1.99 & F arithmetic $<$ F table & Equal Variance Assumed \\
Income & 1.41 & 1.99 & F arithmetic $<$ F table & Equal Variance Assumed \\
\hline
\end{tabular}

Source: From Primary Data Processing 2018

From the results of hypothesis testing $\mathrm{T}$ test in the table (annex 17 and 18) result for the variable production of $\mathrm{T}$-count value $=0.83$, for the variable price of $\mathrm{T}$-count value $=1.69$, for the variable costs of farming the value of T-count $=1,12$ and for the income variable value of T-count $=0.96$, while for T-table $=1.99$. T-count for each variable <T-tables mean $\mathrm{H} 0$ rejected and $\mathrm{H} 1$ accepted so that it can be concluded that there are no significant differences between production, prices, costs and incomes of cocoa farmers are not getting to the get the program SLK. The following table $T$ test of hypothesis testing:

Table.23: T test Hypothesis Testing

\begin{tabular}{lcccl}
\hline \multicolumn{1}{c}{ Component } & T-count & T-table & result & \multicolumn{1}{c}{ Decision } \\
\hline Production & 0.83 & 1.66 & T arithmetic <T table & H0 \\
Price & 1.69 & 1.66 & T arithmetic $>\mathrm{T}$ table & H0 is rejected \\
Farming costs & 1.12 & 1.66 & $\mathrm{~T}$ arithmetic $<\mathrm{T}$ table & H0 \\
Income & 0.96 & 1.66 & T arithmetic $<\mathrm{T}$ table & H0 \\
\hline
\end{tabular}

Source: From Primary Data Processing 2018.

The above table shows that there are significant differences in terms dar cocoa selling prices received by farmers and farmers Non SLK SLK. This means that farmers SLK has been able to create quality cocoa beans 
that better so that when sales are also rewarded with a higher price. But in terms of production, Farming Costs and Revenues. there was no significant difference between the farmers who mendapakatkan SLK (SCPP Swisscontact) to farmers who did not get the SLK. From the results of the review discussion with farmers in the field and it happened because:

- Most of the farmers who are members of the SCCP is a woman farmer program while the more intensive work in the garden is a male farmer making the transfer of technology was not optimal.

- Most cocoa farmers who are members of SCPP program is farmers who have land area under $1 / 4 \mathrm{Ha}$ cocoa and cocoa plantation is not a primary means of livelihood. Dikabupaten Fifty Cities for farmers especially its main business of respondents majority of farmers are farming rice paddy, pulses, gambier plantations and farms.

- The majority of routine activities diperkebunan cocoa farmers only harvest and pruning melakukukan light.

- Judging from the level of technology adoption only a small proportion of farmers who are able to adopt all the technology components remaining only a few components are adopted when all components are interlinked with each other to support the production and quality of cocoa beans produced, es pecially those components PsPSP (Harvest often, pruning, Sanitas and Fertilization).

\section{CONCLUSIONS AND RECOMMENDATIONS}

\section{Conclusion}

The results showed thatthere are significant differences in terms of selling prices of cocoa beans received by farmers This means that the farmers participating in the SLK has been able to create quality cocoa beans are better than non-participant farmers SLK. But in terms of production, Farming Costs and Revenues. there was no significant difference between the farmers participating in the SLK (SCPP Swisscontact) with a non-participant farmers SLK. Soit can be concluded that cocoa field school program provided by Swisscontact no significant impact on cocoa farmers in the district Fifty Cities.

\section{Recomendation}

From the above conclusions, it is recommended that farmers can continue to be guided and monitored in a given application of the technology component. For farmers who receive coaching to be more active doing garden maintenance in order to get more production with a minimum of routine applying the core technology that is PsPSP (Harvest often, pruning, and fertilizing the garden Sanitation), and can share their knowledge with other farmers.

\section{REFERENCES}

[1] Directorate General of Plantation. 2012.Technical Guidelines for Integrated Pest Management Field School (FFS-IPM) Crops 2013. Jakarta: Secretariat of the Directorate General of Plantation.

[2]

2014. Technical guidelines for the cultivation of cocoa, 2014. Jakarta: Secretariat of the Directorate General of Plantation.

[3] .2016. Statistics Indonesia Plantation. www.ditjenbun.pertanian.go.id.

[4] FAO. 2017 Global Farmer Field School Platform. http://www.fao.org/farmer-

fieldschools/overview/en/ United Nations. Regional Office for Asia and the Pacific. Bangkok.

[5] Gulo, W. 2002. Research Methods. Jakarta: PT. Grasindo.

[6] Kasmadi and Nia Sri Sunariah. 2013. Quantitative Research Modern Guide. Bandung: Alfabeta.

[7] Nazir, Moh. 2005. Methods Penelitian.Jakarta: Ghalia Indonesia.

[8] Cocoa SIKKA Learning Center. 2013. cocoa field school.

https://kakaosikka.wordpres s.com/2013/09/21/s ekol ah-lapangan-kakao/.

[9] Estate Crops Research and Development Center. 2017 Indonesian Center for Estate Crops Research and Development. http://perkebunan.litbang.pertanian.go.id/?p=4147.

[10] Saputra, Ardhiyan. 2015. Factors Affecting the Production of Cocoa In Muaro Jambi. Department of Agribusiness Faculty of Agriculture, University of Edinburgh. ISSN, 2015.

[11] Swisscontact. 2014. The basic module cocoa cultivation practices. www.s wis scontact.org,

[12] Sugiyono. 2008. Qualitative Research Methods Kunatitatif and R \& D. Bandung Alfabeta.

[13] Zulhefi, Sikumbang. 2015. Chairman of Indonesian Cocoa Association (ASKINDO). http://118.97.35.230/download/29072010/sriambardi ni/MIPA/perubahan/ content / fat / seed / kakao.doc. Date of June 19, 2015. 